Revista Brasil. Bot., V.31, n.3, p.491-497, jul.-set. 2008

\title{
Cyanoaggregatum brasiliense gen. et sp. nov., a new chroococcal Cyanobacteria from Southern Brazil
}

\author{
VERA REGINA WERNER ${ }^{1,3}$, CÉLIA LEITE SANT'ANNA² and \\ MARIA TERESA DE PAIVA AZEVEDO ${ }^{2}$
}

(received: August 24, 2006; accepted: June 26, 2008)

\begin{abstract}
Cyanoaggregatum brasiliense gen. et sp. nov., a new chroococcal Cyanobacteria from Southern Brazil). The paper proposed Cyanoaggregatum brasiliense, a new genus and species from the plankton of a subtropical brackish coastal lagoon from Rio Grande do Sul State, South Brazil. It differs from all other members of Chroococcales by its characteristic arrangement of cells in irregular groups distributed in a single, flat or slightly curved layer, on irregular rows, slightly distant from each other, forming a mosaic-like pattern slightly below the surface of the mucilaginous colonial envelope. The cell division in one plane perpendicular to the long axis and the lack of pseudo-filaments indicate its classification in the family Synechococcaceae, sub-family Aphanothecoideae. The general characteristics, the diagnostic criteria and the taxonomic position are discussed, and a comparison between Cyanoaggregatum and its most closely related genera is presented. Physical and chemical data on the studied lagoon and geographical distribution are presented.
\end{abstract}

Key words - coastal lagoon, Cyanoaggregatum brasiliense, Cyanobacteria, new genus and species, southern Brazil

RESUMO - (Cyanoaggregatum brasiliense gen. et sp. nov., uma nova cianobactéria (Chroococcales) do sul do Brasil). O trabalho propõe Cyanoaggregatum brasiliense, gênero e espécie novos, encontrado no plâncton de lagoa costeira salobra, subtropical, do Estado do Rio Grande do Sul, sul do Brazil. O novo gênero difere dos demais membros da ordem Chroococcales pela disposição característica de suas células em grupos irregulares, planos ou levemente curvos, constituídos por uma camada de células, dispostas em fileiras irregulares, levemente distantes umas das outras, formando padrão semelhante a um mosaico, na periferia do envelope mucilaginoso. A divisão celular em um único plano, perpendicular ao eixo maior e a ausência de pseudofilamentos permitiram classificar estas populações na família Synechococcaceae, subfamília Aphanothecoideae. As características gerais, a diagnose e a posição taxonômica do novo táxon são discutidas. São apresentadas comparações entre Cyanoaggregatum e os gêneros mais próximos, assim como dados físicos e químicos referentes ao local-tipo e sua distribuição geográfica.

Palavras-chave - Cyanoaggregatum brasiliense, Cyanobacteria, gênero e espécie novos, lagoa costeira, sul do Brasil

\section{Introduction}

The Coastal Plain of Rio Grande do Sul State, in the southern region of Brazil, presents a complex system of lagoons, constituting an ecosystem with peculiar limnological characteristics, suffering influence of both marine and continental waters.

During the floristic studies of cyanobacteria from coastal lagoons of Rio Grande do Sul State, a special type of planktonic coccoid was found in Custódias Lagoon. This brackish environment belongs to the Tramandaí system, which is constituted of a group of lagoons interconnected by canals and forming a parallel sequence with the sea shore. These lagoons are permanently connected to the sea through the Tramandaí Canal, suffering

\footnotetext{
1 Museu de Ciências Naturais, Fundação Zoobotânica do Rio Grande do Sul, Caixa Postal 1188, 90001-970 Porto Alegre, RS, Brazil.

2. Instituto de Botânica, Seção de Ficologia, Caixa Postal 3005, 01061-970 São Paulo, SP, Brazil.

3. Corresponding author: vrwerner@fzb.rs.gov.br
}

variations in the salinity values as a consequence of the inflow of water from the Atlantic Ocean. According to Chomenko \& Schäfer (1984) the lagoons show typical estuarine characteristics.

The studied population displays a group of features that makes it different from other members of Chroococcales: a. colonies hollow, formed by irregular groups of cells distributed in a single, flat or slightly curved layer, on irregular rows, slightly distant from each other, mosaiclike, at the colonial envelope mucilaginous surface; $b$. cell division in one plane; c. planktonic habitat mainly in brackish water. Based on these points, we are presently proposing a new genus and species belonging to the family Synechococcaceae, subfamily Aphanothecoideae.

\section{Material and methods}

Study area - Custódias Lagoon is located in the north of the lagoons system of the Coastal Plain of Rio Grande do Sul State, South Brazil $\left(30^{\circ} 01^{\prime} \mathrm{S}-30^{\circ} 03^{\prime} \mathrm{S}\right.$ and $\left.50^{\circ} 10^{\prime} \mathrm{W}\right)$ (figure 1). This subtropical brackish ecosystem belongs to 
the groups of lagoons located in the south of the Tramandaí system and is approximately $7 \mathrm{~km}$ distant from the Tramandaí Canal. According to Schäfer (1988), based on the size and depth of the coastal lagoons of Rio Grande do Sul, Custódias is considered a small and shallow lagoon. Its surface area is $9.58 \mathrm{~km}^{2}$ and the volume is $10.54 \times 10^{6} \mathrm{~m}^{3}$ and the average depth is $1.10 \mathrm{~m}$ (Schwarzbold \& Schäfer 1984). Some limnological data registered during the sample's collecting period at three sites of the Custódias Lagoon are expressed in table 1.
The lagoon shows a diversity of aquatic macrophytes which change according to the variations of the salinity values (Schwarzbold 1982). The community of algae is rich, composed essentially of diatoms and cyanobacteria.

The samples were collected with plankton net $(25 \mu \mathrm{m}$ mesh), from April 1979 to June 1981, at three collecting sites: one at the central zone of the lagoon, and the other two at the north and at the south, near the canals Camarão and Relógio, respectively (figure 1). They were preserved in Transeau solution and included in the Prof. Dr. Alarich R.H.
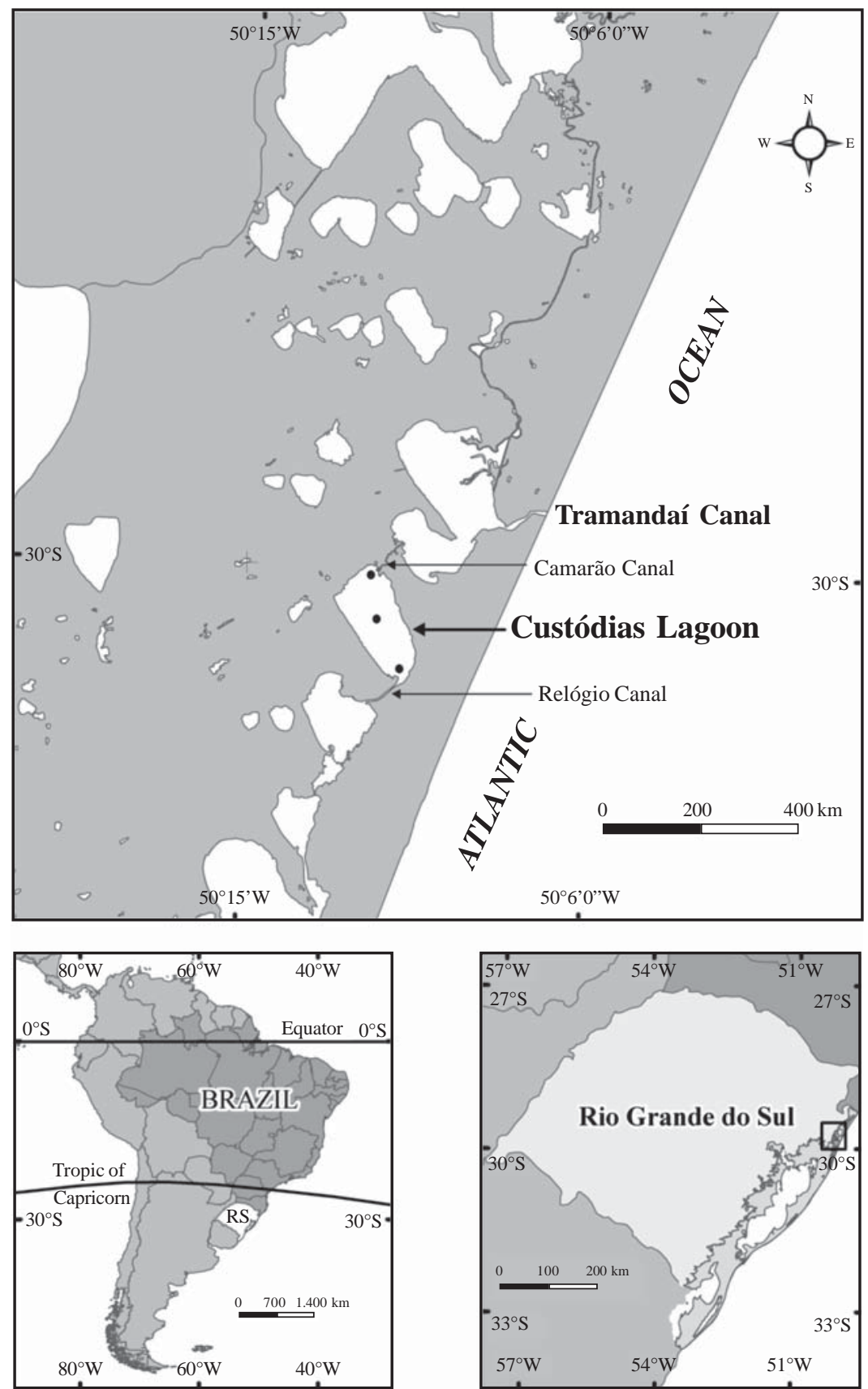

Figure 1. Map showing the coastal lagoon system of Rio Grande do Sul State (RS), Brazil, and, in detail, the northern region $(\square)$ of the system indicating Custódias Lagoon. 
Table 1. Average and range (minimum-maximum) of some limnological parameters for the three Custódias lagoon collecting sites between April 1979 and March 1981. $(\mathrm{N}=$ north; $\mathrm{C}=$ central zone; $\mathrm{S}=$ south).

\begin{tabular}{|c|c|c|c|c|c|c|}
\hline \multirow{2}{*}{ Collecting sites } & \multicolumn{2}{|c|}{$\mathrm{N}$} & \multicolumn{2}{|c|}{$\mathrm{C}$} & \multicolumn{2}{|c|}{$S$} \\
\hline & Average & Range & Average & Range & Average & Range \\
\hline Salinity $(\% o)$ & 3.9 & $1.1-10.7$ & 2.7 & $1.0-7.0$ & 1.1 & $0-6.5$ \\
\hline Temperature $\left({ }^{\circ} \mathrm{C}\right)$ & 18.7 & $14.0-22.5$ & 20.5 & $13.0-27.0$ & 19.5 & $13.0-27.5$ \\
\hline $\mathrm{pH}$ & 7.2 & $6.2-8.2$ & 7.4 & $6.9-8.2$ & 6.8 & $6.2-8.1$ \\
\hline Depth (m) & 1.35 & $1.20-1.50$ & 1.30 & $1.10-1.60$ & 0.90 & $0.50-1.20$ \\
\hline Secchi depth (m) & 1.10 & $0.60-1.40$ & 1.10 & $0.60-1.20$ & 0.80 & $0.50-1.10$ \\
\hline
\end{tabular}

Schültz Herbarium (HAS), Porto Alegre, Rio Grande do Sul, Brazil. For each sampling station, water temperature $\left({ }^{\circ} \mathrm{C}\right)$, salinity concentrations $(\% o)$, and eletric conductivity $\left(\mu \mathrm{S} \mathrm{cm}^{-1}\right)$ were obtained with the help of a Yellowspring (model 33) thermosalinometer, and $\mathrm{pH}$ with a Digimed portable potentiometer. Total depth $(\mathrm{m})$ and transparence $(\mathrm{m})$ were measured, whith meter and Secchi disc, respectively. Data concerning the samples where Cyanoaggregatum brasiliense gen. et sp. nov. were recorded and their physical and chemical parameters are presented in table 2.

The material was studied under optical microscope and the photos were taken using a Zeiss Axioplan-2 microscope equipped with phase contrast and Optovar lens. The classification system of Komárek \& Anagnostidis (1998) was adopted.

Table 2. Data concerning the samples where Cyanoaggregatum brasiliense was recorded, and their physical and chemical parameters. $(\mathrm{N}=$ north; $\mathrm{C}=$ central zone; $\mathrm{S}=$ south; HAS = register numbers in the Prof. Dr. Alarich R.H. Schultz Herbarium).

\begin{tabular}{|c|c|c|c|c|c|c|c|c|c|c|}
\hline \multirow{2}{*}{$\begin{array}{l}\text { Collecting sites } \\
\text { Date }\end{array}$} & \multicolumn{7}{|c|}{$\mathrm{N}$} & \multicolumn{2}{|c|}{$\mathrm{C}$} & \multirow{2}{*}{$\begin{array}{c}\text { S } \\
\text { Feb. } \\
1981\end{array}$} \\
\hline & $\begin{array}{l}\text { Apr. } \\
1979\end{array}$ & $\begin{array}{l}\text { Sept. } \\
1980\end{array}$ & $\begin{array}{c}\text { Oct. } \\
1980\end{array}$ & $\begin{array}{l}\text { Nov. } \\
1980\end{array}$ & $\begin{array}{l}\text { Dec. } \\
1980\end{array}$ & $\begin{array}{l}\text { Jan. } \\
1981\end{array}$ & $\begin{array}{l}\text { Fev. } \\
1981\end{array}$ & $\begin{array}{c}\text { Oct. } \\
1980\end{array}$ & $\begin{array}{l}\text { Mar. } \\
1981\end{array}$ & \\
\hline Salinity $(\% o)$ & 10.7 & 7.1 & 3.2 & 3.1 & 1.0 & 2.0 & 1.0 & 2.2 & 2.5 & 0 \\
\hline Temperature $\left({ }^{\circ} \mathrm{C}\right)$ & 21.0 & 14.5 & 18.0 & 22.50 & 25.0 & 25.0 & 27.0 & 18.8 & 24.0 & 27.5 \\
\hline $\mathrm{pH}$ & 8.2 & 7.1 & 7.0 & 7.1 & 7.5 & 7.6 & 8.2 & 7.0 & 7.0 & 7.0 \\
\hline Conductivity $\left(\mu \mathrm{Scm}^{-1}\right)$ & 1,700 & 6,800 & 5,800 & 5,200 & 2,500 & 3,800 & 1,850 & 4,000 & 2,700 & 2,700 \\
\hline Oxygen dissolved (\%) & 8.2 & 10.30 & 11.8 & 8.1 & 7.9 & 7.0 & 7.5 & 13.3 & 8.4 & 7.0 \\
\hline Depth (m) & 1.30 & 1.35 & 1.40 & 1.50 & 1.40 & 1.40 & 1.20 & 1.15 & 1.40 & 0.90 \\
\hline Secchi depth (m) & 1.30 & 0.70 & 0.90 & 1.10 & 1.20 & 0.85 & 1.10 & 1.00 & 0.90 & 0.90 \\
\hline HAS & 6897 & 2220 & 26206 & 22230 & 26229 & 26232 & 26236 & 26223 & 26240 & 26237 \\
\hline
\end{tabular}

\section{Results}

Cyanoaggregatum Werner, Sant'Anna et Azevedo gen. nov. $A b$ omnibus generibus (fam. Synechococcaceae) cellulis irregularibus in seriebus disppositis in strato singuli, strato plano vel liviter curvato, seriebus irregularibus, leviter distantibus intra se, mosaicis similibus, sitis leviter infra supeficiem involucri mucilaginis colonialis differt.

Species typica: Cyanoaggregatum brasiliense Werner, Sant'Anna et Azevedo sp. nov.
Colonies hollow, initially rounded, later elongated, usually irregular in outline, composed of many irregular groups of cells; mucilage firm, thick, homogeneous, colourless, hyaline; cells oval or cylindrical with rounded ends, disposed in a single flat or slightly curved layer, on irregular rows, slightly distant from each other, mosaic-like pattern, slightly below the surface of the mucilaginous colonial envelope; without aerotopes; cell division symmetrical by binary fission in one plane perpendicular to the long axis; reproduction by proliferation of daughter colonies from the oldest ones. 
Cyanoaggregatum brasiliense Werner, Sant'Anna et Azevedo sp. nov.

Typus: BRAZIL. Rio Grande do Sul: Tramandaí, Lacus Custódias, 1-IV-1979, V.R. Werner, s.n. (HAS 6897).

Figures 2-8

Coloniae liberae, natantes, microscopicae, cavae, rotundatae vel elongatae, 62.0-160.0 $\mu \mathrm{m}$ latae, 92.0-340.0 um longae; vagina firma, homogenea, incolor, hyalina; cellulae ovatae vel teretes apicebus rotundatis, sine singulis mucosis involucris, 1.5-2.3 longiores quam latiores, 2.4-3.8 $\mu \mathrm{m}$ longae, 1.4-2.0 $\mu \mathrm{m}$ latae (in medio $1.68 \times 3.06 \mu m \pm 0.18 \times 0.45 ; n=23$ ); cellulae compactae disppositae in catervis superficie vaginae strato unico; strato plano vel leviter curvato, seriebus irregularibus, liviter distantibus, mosaicis similibus, sitae leviter infra superficiem involucri coloniali mucosi, contentum cellulare viridi-fuscum, homogeneum, sine aerotopis; divisio cellularis plano singulari ad axem perpendicularem; efformatio coloniarum filiarum a coloniis veternis.

Colonies free-floating, hollow, microscopic, rounded or elongated, 62.0-160.0 $\mu \mathrm{m}$ diameter, 92.0-340.0 $\mu \mathrm{m}$ long;
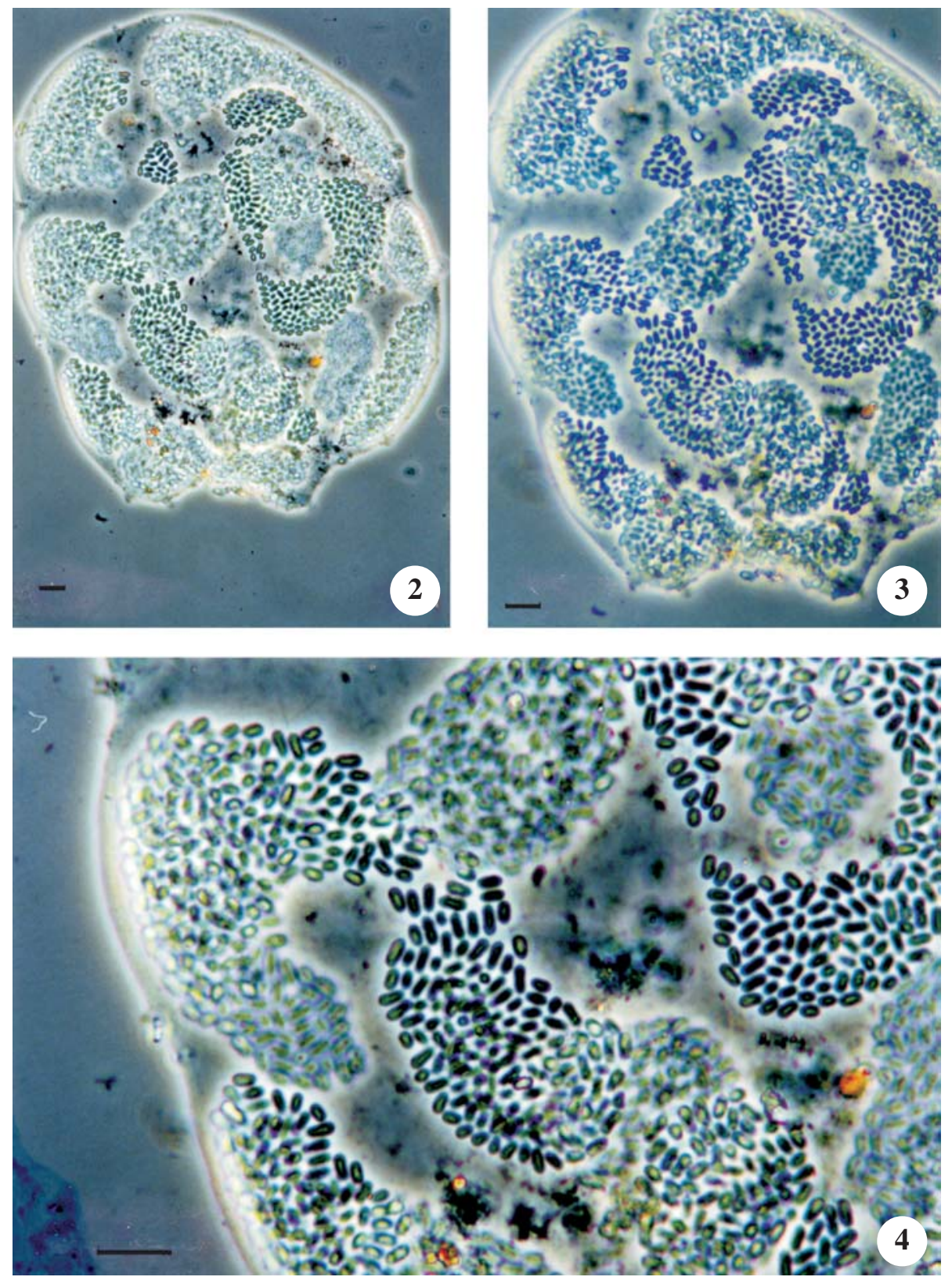

Figures 2-4. Cyanoaggregatum brasiliense. 2. General aspect of a colony. 3. Part of the colony showing groups of cells. 4. Detail of some groups showing the disposition of the cells. $(\mathrm{bar}=10 \mu \mathrm{m}$.) 
mucilaginous envelope firm, thick, homogeneous, colorless, hyaline; cells oval or cylindrical with rounded ends, without individual mucilaginous envelopes, 1.5-2.3 times longer than wide, 1.4-2.0 $\mu \mathrm{m}$ diameter, 2.4-3.8 $\mu \mathrm{m}$ long (average of $1.68 \times 3.06 \mu \mathrm{m}$ and standard deviation of $0.18 \times 0.45 ; n=23$ ), disposed in irregular groups, in a single, flat or slightly curved layer, on irregular rows, slightly distant from each other, mosaic-like pattern, slightly below the surface of the mucilaginous colonial envelope; cell content blue-green, homogeneous, without aerotopes; cell division in one plane perpendicular to the long axis; daughter colonies formed from oldest ones.

\section{Discussion}

Cyanoaggregatum brasiliense is distinct from other colonial chroococcal cyanobacteria by its hollow colonies, with the characteristic arrangement of the cells in groups distributed slightly below the surface of the mucilaginous colonial envelope. Based on the cell division being in
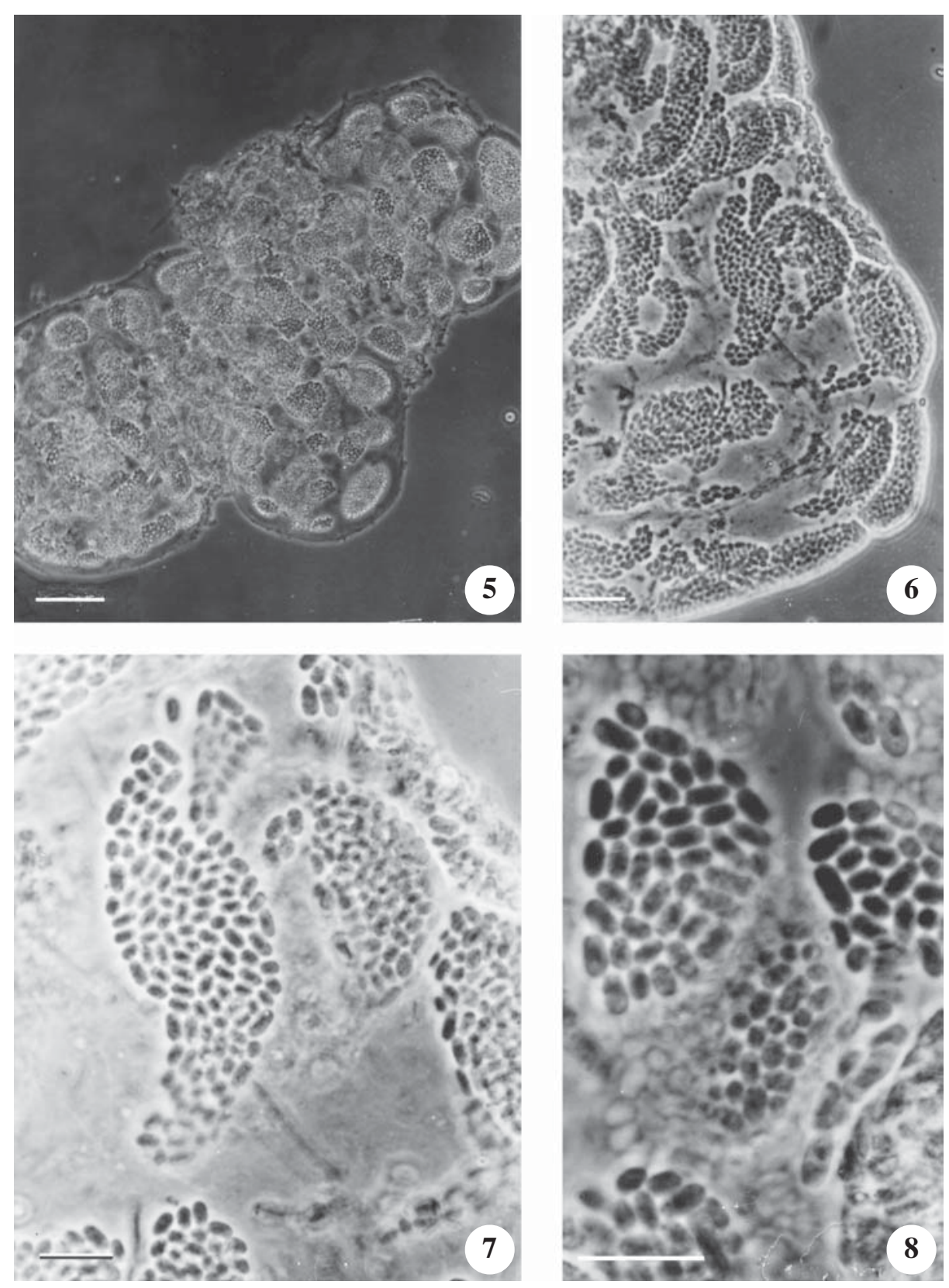

Figures 5-8. Cyanoaggregatum brasiliense. 5-6. General aspect of a colony with a daughter colony formation. 7. Part of the colony showing groups of cells. 8 . Detail of some groups showing the cells disposition in rows. $(\mathrm{bar}=10 \mu \mathrm{m}$.) 
one plane and by lacking pseudo-filaments, we consider this species belonging to the family Synechococcaceae, sub-family Aphanothecoccoide.

Aphanothece Nägeli is the closest genus of Cyanoaggregatum, similar mainly by the shape of the cells but they differ essentially by the distribution of the cells in the colonial mucilage (table 3). Cyanoaggregatum brasiliense is similar to Aphanothece conglomerata Rich and A. elabens (Brébisson) Elenkin due to the disposition of their cells in groups but, in these species each group of cells is surrounded by a hyaline, sometimes lamellate mucilaginous envelope. These groups, in fact, constitute several colonies aggregated together. These species also differ from $C$. brasiliense because their cells are densely and irregularly arranged within the mucilage and by the size of their cells.

Cyanogastrum, described by Schiller (1956) from the island "Los Aves" (Venezuela) in the Caribbean Sea, is another genus that could be compared to Cyanoaggregatum (table 3). Schiller collected his material in pools on an old coral, at the shore of the island, with $40 \%$ salinity and with red-water by the presence of Peridinium sp. The typical cell arrangement observed in Cyanoaggregatum brasiliense has some similarity with Cyanogastrum variabilis, the type species of the genus. Nevertheless, they differ, especially, because the cells of Cyanogastrum are disposed in 1-2 layers around a lens-shape cavity, agglomerate, sometimes slightly flattened where they touch each other, while in Cyanoaggregatum they are distributed in a single, flat or slightly curved layer, on irregular rows, distinctly distant from each other, arranged in irregular groups, mosaic-like patterns. Besides, the typical colony of Cyanogastrum is quite different from the colonies of the new genus. According to Schiller (1956), the old colonies of Cyanogastrum usually are arch shaped having one end always more widely round than the opposite end. This kind of colony has never been found in the Brazilian populations and only rounded or elongated colonies were recorded. Both genera also differ by the cell organization in rows. In Cyanoaggregatum they are, usually, disposed side by side, while in Cyanogastrum, end to end.

On the other hand, Komárek (1995) recognized three subgenera in the Aphanothe genus, one of them based in the characteristics of Aphanothece variabilis (Schiller) Komárek, described from tropical populations obtained on Cuban aquatic environments, and classified the species in the sub-genus Cyanogastrum. Thus, according to Komárek (1995) and Komárek et Anagnostidis (1998), Aphanothece comprises the sub-genera, Anathece, Aphanothece and Cyanogastrum.

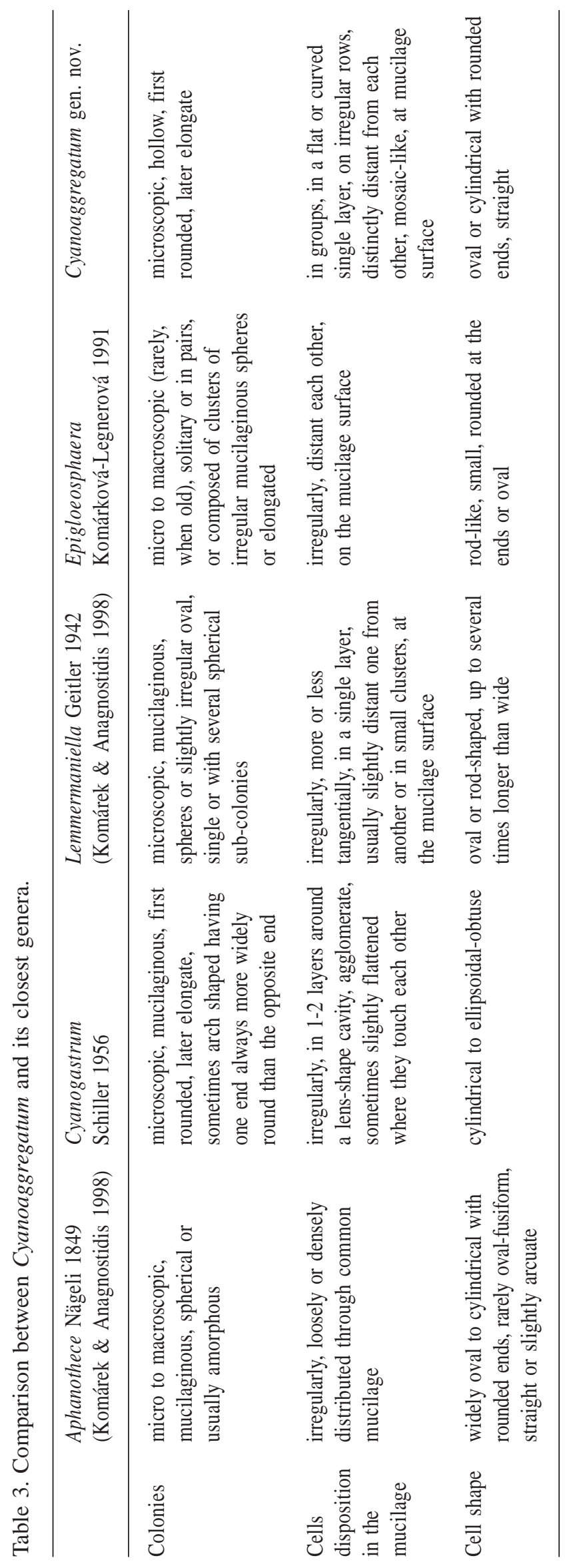


Although, Aphanothece seems to be a heterogeneous genus, Cyanoaggregatum clearly differs from it by its typical arrangement of the cells in the characteristic groups, disposed slightly below the surface of the mucilaginous colonial envelope.

Lemmermaniella Geitler and Epigloeosphaera Komárková-Legnerová also have the cells disposed in a single layer at the periphery of the mucilaginous colonial envelope; however, they are not arranged in the characteristic groups as in Cyanoaggregatum. Besides, in the two former genera the colonies are mucilaginous sphere, and the typical position of the cells of Epigloeosphaera, on the surface of colonies, is quite different. These genera also differ by the shape of their cells. (table 3 ).

Considering that cells distribution in the mucilaginous colonial envelope is a very important feature for the intergeneric taxonomy of the sub-family Aphanothecoideae, the typical arrangement of the cells in groups, slightly below the surface of the mucilaginous colonial envelope, clearly distinguishes Cyanoaggregatum from its most closely related genera. The new genus and species described from a Brazilian subtropical, brackish water coastal lagoon, are a special type, which cannot identified with all other genus existent in the specialized literature, such as Geitler (1932), Komárek (1995), Komárek \& Anagnostidis (1998), Komárek \& Cronberg (2001), and Sant'Anna et al. 2004.

Cyanoaggregatum brasiliense was found in plankton and stood out by the highest number of organisms in the samples obtained at the north of the Custódias Lagoon. Although its frequency in both sites, north and central zone of the lagoon, was similar during the collecting period, in the center just a few specimens were recorded. In the south of the lagoon, local where the lowest salinities were registered, its occurrence was sporadic and only one colony in a freshwater sample was observed. This fact suggests that the new species grow preferentially in water with slightly higher salt concentrations (1.1-10.7\%o, average of 3,9\% - table 1).

Besides Custódias Lagoon, $C$. brasiliense was also observed in the central zone of the Patos Lagoon, in a planktonic sample with salinity of $0.20 \%$ (Lezilda Torgan, personal communication). It was also recorded in plankton of Carapebus Lagoon, a brackish tropical coastal lagoon, on the north coast of Rio de Janeiro State, Brazil and identified as Aphanothece conglomerata Rich (Azevedo et al. 1999-figure 24). The variation of salinity of Carapebus Lagoon, where $C$. brasiliense was observed, registered by the authors, was close to those recorded in Custódias Lagoon. According to Azevedo et al. (1999), the species was also recorded in Araruama Lagoon, a hyper-saline lagoon in Rio de Janeiro State (unpublished data).
The observation of $C$. brasiliense in different Brazilian coastal lagoons suggests that it is typical of this type of ecosystem, especially growing in brackish water, and probably tolerant to wide variations of salinity.

Acknowledgements - to Dr. Jíri Komárek for his valuable comments, to CNPq (Grant 141.699/95-7) and Fapergs (Grant 22-78) for the financial support of the first author, and to Dr. Tarciso S. Filgueiras for the help in the Latin diagnosis.

\section{References}

AZEVEDO, M.T.P., SOUZA, C.A. \& MENEZES, M. 1999. Synechococcaceae (Cyanophyceae/Cyanobacteria) from a tropical brackish water lagoon, Brazil. Algological Studies 94:45-61.

CHOMENKO, L. \& SCHÄFER, A. 1984. Interpretação biogeográfica da distribuição do gênero Littoridina (Hydrobiidae) nas lagoas costeiras do Rio Grande do Sul, Brasil. Amazoniana 9:127-146.

GEITLER, L. 1932. Cyanophyceae. In Kryptogamenflora von Deutschland, Österreich und der Schweiz (T.L. Rabenhorst ed.). Akademische Verlagsgesellschaft, Leipzig, part 2, v.14, p.1-1196.

KOMÁREK, J. 1995. Studies on the cyanophytes (Cyanoprokariotes) of Cuba 10. New and little know chroococcalean species. Folia Geobotanica et Phytotaxonomica 30:81-90.

KOMÁREK, J. \& ANAGNOSTIDIS, K. 1998. Cyanoprokaryota. 1: Chroococcales. In Süsswasserflora von Mitteleuropa. (H. Ettl, G. Gardner, H. Heynig \& D. Mollenhauer, eds.). Gustav Fischer, Jena, v.19, p.1548.

KOMÁREK, J. \& CRONBERG, G. 2001. Some chroococcalean and oscillatorialean Cyanoprokaryotes from southern African lakes, ponds and pools. Nova Hedwigia 73:129160.

SANT'ANNA, C.L., AZEVEDO, M.T.P., SENNA, P.A., KOMÁREK, J. \& KOMÁRKOVÁ, J. 2004. Planktic Cyanobacteria from São Paulo State, Brazil: Chroococcales. Revista Brasileira de Botânica 27:213-227.

SCHÄFER, A. 1988. Tipificação ecológica das lagoas costeiras do Rio Grande do Sul, Brasil. Acta Limnologica Brasilia 2:29-55.

SCHILLER, J. 1956. Die Mikroflora der roten Tümpel auf den Koralleninseln "Los Aves" im Karibischen Meer. Deutsscher Verlag der Wissenschafte Berlin. 1:197-211.

SCHWARZBOLD, A. 1982. Influência da morfologia no balanço de substâncias e na distribuição de macrófitas aquáticas nas lagoas costeiras do Rio Grande do Sul, Dissertação de mestrado - Universidade Federal do Rio Grande do Sul, Porto Alegre.

SCHWARZBOLD, A. \& SCHÄFER, A. 1984. Gênese e morfologia das lagoas costeiras do Rio Grande do Sul - Brasil. Amazoniana 9:87-104. 